\title{
Interferons: \\ Antiangiogenesis agents (a reasonable theory)
}

\author{
JOSEPH G SINKOVICS, MD, FACP
}

\begin{abstract}
JG Sinkovics. Interferons: Antiangiogenesis agents (a reasonable theory). Can J Infect Dis 1992;3 (Suppl B):128B-132B. Antiviral and immunomodulatory effects of interferons (IFNs) are well-known. This communication lists arguments for explicit antiangiogenetic effects exerted by interferons. There is strong likelihood that IFNs $\alpha, \beta$ and $\gamma$ inhibit the int family of genes whose gene product proteins are the acidic and basic fibroblast growth factors. Some of these growth factors promote the growth of vascular endothelial cells. IFN- $\alpha$ inhibits basic, and IFN- $\gamma$ inhibits acidic fibroblast growth factors. Inhibition of Kaposi sarcoma cell growth is not due to immunological reconstitution of the host. As IFN- $\alpha$ induces clinical remissions but IFN- $\gamma$ does not, basic and not acidic fibroblast growth factor should be implied as one of the proliferation-inducing factors of Kaposi sarcoma cells. IFNs may interfere with the growth promotional activity of the human immunodeficiency virus Tat protein on Kaposi sarcoma cells. The proliferation of certain melanoma cell populations requires fibroblast growth factors. If this mechanism is mediated through amplified int genes, IFNs may be active clinically in this subset of melanomas. Some breast carcinoma cells induce neovascularization and metastasize. If this activity is mediated through amplified int genes, IFNs may be active clinically in this subset of breast carcinomas.
\end{abstract}

Key Words: Angiogenesis, Antiangiogenesis, Human immunodeficiency virus-tat, Interferons, Interleukins, Proto-oncogenes hst-int, Transforming growth factor- $\beta$

\section{Interférons: agents anti-angiogénèse (théorie plausible)}

Les effets antiviraux et immuno-modulateurs des interférons (IFN) sont bien connus. Le présent document énumère les arguments à l'appui des effets anti-angiogénétiques explicites qu'exercent les interférons. Tout porte à croire que les interférons $\alpha, \beta$ et y inhibent la famille int des gènes dont les produits proteiqes sont les facteurs de croissance fibroblastiques acides et basiques. Certains de ces facteurs de croissance favorisent la croissance des cellules endothêliales vasculaires. L'IFN- $\alpha$ inhibe les facteurs basiques et l'IFN- $\gamma$ inhibe les facteurs de croissance fibroblastiques acides. L'inhibition de la croissance des cellules du sarcome de Kaposi n'est pas attribuable à la reconstitution immunologique de l'hôte. Comme l'IFN- $\alpha$ induit des rémissions cliniques contrairement à l'IFN- $\gamma$, les facteurs de croissance fibroblastiques basiques et non pas les facteurs acides, doivent être soupçonnés d'induire la prolifération des cellules du sarcome de Kaposi. Les IFN peuvent interférer aviec l'activité des protéines VIH-Tat qui favorisent la croissance des cellules du sarcome de Kaposi. La prolifération de certaines populations de cellules de mélanomes requiert la participation des facteurs de croissance fibroblastiques. Si ce mécanisme est modulé par le recours à des gènes int amplifiés, les IFN peuvent se révéler cliniquement actifs dans ce sous-groupe de cancers du sein.

Cancer Institute, St Joseph's Hospital, Departments of Medicine and Medical Microbiology. University of South Florida College of Medicine, Tampa, Florida, USA

Correspondence and reprints: Dr JG Sinkovics, Cancer Institute, St Joseph's Hospital, 3001 West Dr ML King Jr Boulevard,

Tampa, FL 33677-4227, USA 
A RECENT REPORT DESCRIBES SUCCESSFUL TREATMENT OF pulmonary hemangiomatosis in a 12-year-old boy with human recombinant interferon-alpha2a ( $\left.\mathrm{Hu}-\mathrm{r}-\mathrm{IFN}-\alpha_{2 \mathrm{a}}\right)$ (1). An enthusiastic editorial reviews tumour-induced angiogenesis and its agonists and antagonists (2). Neither of these articles mentions important animal data. Sidky and Borden (3) showed that murine and human IFN- $\beta$ inhibited tumour-induced angiogenesis in species-specific fashion and IFNs $\alpha, \beta$ and $\gamma$ also inhibited lymphocyte-induced angiogenesis. They proposed that IFNs suppressed the release of certain (not all) angiogenesis-inducing factors from tumour cells and lymphocytes, even when IFNs exerted no inhibitory effect on the replication of the tumour cells or lymphocytes (3).

Based on this work, the author proposed (in the plenary lecture on Kaposi's sarcoma at the 14th International Cancer Congress in 1986) that IFN- $\alpha$ suppressed the growth of acquired immune deficiency syndrome (AIDS)-related Kaposi's sarcoma by directly antagonizing angiogenesis and not indirectly by restoring immunocompetence (4). Data on the possible restoration of immunocompetence in AIDS by IFN treatment remain inconclusive. As recently as 1988, statements like this appear: ". . . no significant changes in immunological function were noted during treatment with IFN- $\alpha$; peripheral blood CD4 percentages, natural killer cell number and activity, and antigen- and mitogen-induced blast transformation were essentially unchanged" (5). It appears that patients with high pretreatment CD4 cell counts respond best to IFN (6). A response rate of $45 \%$ was observed in patients with AIDS-Kaposi's sarcoma circulating more than 400 CD4 cells $/ \mathrm{mm}^{3}$ (7). Patients with high endogenous acid labile IFN- $\alpha$ levels do not respond (8). Even though Hu-r-IFN- $\alpha 2 \mathrm{a}$ and $\mathrm{b}$ reduce human immunodeficiency virus-1 (HIV-1) levels in AIDS (decreased number of isolates from blood lymphocytes and decreased circulating HIV p24 antigen level) $(5,6)$, this virus is not directly involved in the induction of Kaposi's sarcoma in AIDS. Thus, the antiretroviral effect of IFN- $\alpha$ should not directly influence the growth of Kaposi's sarcoma cells.

In analyzing the mechanism of action in AIDSKaposi's sarcoma, a direct growth inhibitory effect of IFNs on endothelial cells was proposed $(4,9)$. IFN- $\beta$ also induces remissions of AIDS-Kaposi's sarcoma (10). IFN- $\gamma$ exerts a strong inhibitory effect on the growth of vascular endothelial cells in vitro and acts antagonistically to alpha endothelial cell growth factor (acidic fibroblast growth factor) which induces proliferation of endothelial cells (11). However, in a few clinical trials, IFN- $\gamma$ acted in AIDS-Kaposi's sarcoma as a weak antiangiogenesis agent $(4,12)$ or it failed to stop progression of disease entirely (10).

If the pathogenesis of AIDS-Kaposi's sarcoma is envisioned properly, the first stimulus derives from retro-

\begin{tabular}{|c|c|c|}
\hline $\begin{array}{l}\text { Growth } \\
\text { factor }\end{array}$ & $\begin{array}{l}\text { KS cells } \\
\text { (clinical) }\end{array}$ & VEC (experimental) \\
\hline IFN- $\alpha$ & Inhibitory & Inhibitory (antagonizes bFGF) \\
\hline IFN- $\beta$ & Inhibitory & Inhibitory \\
\hline IFN- $\gamma$ & $\begin{array}{l}\text { Fails to inhibit } \\
\text { proliferation }\end{array}$ & Inhibitory (antagonizes aFGF) (11) \\
\hline IL-2 & Inhibitory (10) & 'Vascular leakage syndrome' \\
\hline IL-6 & $\begin{array}{l}\text { Autocrine } \\
\text { growth (24) }\end{array}$ & NA \\
\hline TNF- $\alpha$ & NA & $\begin{array}{l}\text { VEC assume elongated shape } \\
\text { Induction of IL-1, G-CSF, } \\
\text { GM-CSF, I-CAM } \\
\text { Proliferation (or necrosis: } \\
\text { apoptosis of VEC) (23) }\end{array}$ \\
\hline $\begin{array}{l}\text { aFGF } \\
\quad(\alpha-E C G F)\end{array}$ & NA & Proliferation \\
\hline bFGF & NA & $\begin{array}{l}\text { Proliferation (angiogenesis; } \\
\text { autocrine growth) (9) }\end{array}$ \\
\hline KFGF & Proliferation & NA \\
\hline
\end{tabular}

CSF Colony stimulating factor: G Granulocyte: I-CAM Cell adhesion molecule; IFN Interferon; IL Interleukin; M macrophage; NA Not applicable

virus-infected T4 cells (13-15). The as yet undefined molecular mediators thus generated induce multifocal growth of endothelial cells. Prominent among these molecular mediators is the tat protein - Tat. This protein promoted the growth of AIDS-Kaposi's sarcoma cells in culture; this activity was neutralized by antibody directed against Tat $(16,17)$. Furthermore, IFN- $\alpha$ activates the $2^{\prime}, 5^{\prime}$ oligoadenylate synthetase system (18). The Tat protein blocks this enzyme system when it binds to Tar encoded by HIV-tar, another activator of this enzyme (19). Thus, IFN- $\alpha$ antagonizes Tat by activating an enzyme system that Tat blocks. Therefore, one of the antiangiogenesis effects of IFN- $\alpha$ rests on its antagonism with Tat over the $2^{\prime}, 5^{\prime}$ oligoadenylate synthetase system.

A second stimulus for the growth of AIDS-Kaposi's sarcoma cells originates in the endothelial cells, where the $\mathrm{K}-f g f$ gene becomes overexpressed leading to the release of its bFGF-like gene product protein that induces autocrine growth since endothelial cells and Kaposi's sarcoma cells also express bFGF receptors. In contrast to $\mathrm{bFGF}$, the $\mathrm{K}-f g f$ gene product protein possesses a hydrophobic signal peptide at its $\mathrm{N}$-terminal (20). Therefore, IFNs may inhibit the growth of Kaposi's sarcoma cells by reducing the release of the initiator growth factor (the first stimulus), probably by inhibiting retroviral replication or by deactivating the $\mathrm{K}-f g f$ gene directly in the endothelial cells, thus depriving Kaposi's sarcoma cells of their autocrine growth factor(s). If this is the case, IFNs act as antagonists of int-hst gene products, ie, are natural antagonists of the bFGF family. Fibroblast growth factor gene expression in AIDSKaposi's sarcoma cells has now been documented by in 


\section{TABLE 2}

\section{Promotion of growth and regression of AIDS-Kaposi's sarcoma (KS) cells: Proposed mechanisms}

\section{Promotion}

Inducing factor(s) derived from HIV-infected T4 cells (14)

bFGF-like molecular mediators derived from KS cells (20)

IL-6 and IL-6R expression by KS cells for autocrine growth (24)

Anti-IFNs and IFN-inactivators (including endogenous acid-labile IFN $\alpha$ ) (8)

TGF $\beta$ production by KS cells (15) antagonizing IL-2 and TNF $\alpha, \beta$; stimulating IL-6 and PDGF production; inducing IL-1R antagonist protein production (42-44)

*Some of these mechanisms of action are only proven in part or are not yet proven experimentally but are logical consequences of interactions that have been proven experimentally. HIV Human immunodeficiency virus; IFN Interferon; IL (R) Interleukin (receptor); PDGF Platelet-derived growth factor: TGF Transforming growth factor

situ hybridization (21). This gene family thus may be another target of antiangiogenesis effect by interferons.

The fact that IFN- $\gamma$, a natural antagonist of aFGF (endothelial cell growth factor- $\alpha$ ), failed to induce remissions in AIDS-Kaposi's sarcoma indicates that the natural driving force of Kaposi's sarcoma cell proliferation is not aFGF because if it were, IFN- $\gamma$ should also have induced remission. The receptor for aFGF possesses tyrosine kinase activity and is encoded by an fmslike gene (22). Table 1 provides an oversimplified account of the effect of growth factors on vascular endothelial cells including those of Kaposi's sarcoma (9).

Another growth factor prominently active in these cells is interleukin (IL)-6. AIDS-Kaposi's sarcoma cells produce IL-6 and express IL-6 receptors; thus, they may use IL-6 as an autocrine growth factor (24). There is a complex interaction of growth factors and their inhibitors affecting angiogenesis in general. For example, IL-1 antagonizes bFGF-receptor expression on endothelial cells and thus breaks the autocrine growth advantage of these cells based on bFGF production. Transforming growth factor-beta (TGF- $\beta$ ) is an antagonist of $\mathrm{IL}-1$ receptor expression while it induces angiogenesis in the chorioallantois membrane of the chicken embryo. This substance is inhibitory to lymphocyte-mediated cytotoxicity and probably acts as a natural antagonist of IL-2. Macrophages of HIV-1-infected patients release TNF- $\alpha$ and IL-1 $\beta$. IL- 4 antagonizes the secretion of tumour necrosis factor-alpha (TNF- $\alpha$ ), IL-1 $\beta$ and IL-6 by monocytes (25). Growth factors acting promotionally on AIDS-Kaposi's sarcoma cells are the Tat protein, K-bFGF, IL-6, granulocytemacrophage colony stimulating factor (GM-CSF), platelet-derived growth factor and the combination of IL-2 and IFN- $\beta$ (Table 2) (25). Locally acting immunosuppressive factors further promoting the growth of these cells are TGF- $\beta$, anti-interferons and probably arachidonic acid-derived prostaglandins. These lesions regress under treatment with IFN- $\alpha$ antagonizing the effects of Tat and/or deactivating the K-FGF proto-oncogene

\section{Regression}

IFN $\alpha$ suppresses genes or gene product proteins of int family* (9)

IFN $\alpha$ activates Tar and 2', $5^{\prime}$ oligoadenylate synthetase thus antagonizing Tat, the inhibitor of this system (19)

TGF $\beta$ switched off* (by mechanism unknown; another possible action of IFN $\alpha$ ?) with consequential cessation of IL-6, PDGF and IL-1R antagonist protein production

IL-1 production* arresting growth of endothelial cells by reducing bFGF-R expression (45)

IL-2 induction* and expansion of T8 lymphocytes cytotoxic to KS cells
(Table 2). Apoptosis of abnormal endothelial cells may ensue under the effects of IFN- $\alpha$ or TNF- $\alpha$ or $\beta$ (lymphotoxin) (23). These latter factors may derive from defensive monocytes-macrophages or T8 lymphocytes and act simultaneously with the cessation of TGF- $\beta$ production (Table 2) (25).

\section{EFFECTS IN OTHER TUMOUR SYSTEMS}

Activation of the hst-int proto-oncogene family occurs in malignant melanoma but without overt and excessive neovascularization $(26,27)$. Yet a subset of these tumours respond to treatment with IFNs (28). In breast carcinoma, neovascularization in a subset of primary tumours correlates with their metastatic potential (29). It is not known which proto-oncogene is amplified to encode angiogenetic growth factors in breast carcinoma. It is known that in a subset of human breast carcinomas, the int family of proto-oncogenes is amplified (30), as it is amplified in murine mammary tumour virus-induced breast carcinomas (31). While IFN did not inhibit the replication of this murine tumour virus, it reduced its oncogenicity (32). It is essential to find out if the subset of breast carcinomas which induces neovascularization possesses amplified int and responds to treatment with IFN, and if IFN could thus prevent the formation of metastases in these subsets of human breast carcinomas. While the majority of melanomas and breast carcinomas fail to respond to IFNs, a small subset do respond. This author proposes that the responsive subset of these tumours operates through activated int family genes and fibroblast growth factors promote their growth. Deactivation of int genes by IFNs could be the mechanism of growth inhibition. However, the actual studies showing such correlation have not as yet been concluded.

Astrocytomas, particularly glioblastoma multiforme, induce excessive neovascularization (33). Treatment with IFN- $\alpha$ results in significant reduction of neovascularization (34). Antitumoral effects of IFNs in these 
systems may be based on deactivation of the int protooncogenes.

While a refined action such as growth factor gene inhibition may be the major effect of IFNs on proliferating vascular endothelial cells, in a virally induced murine leukemia-tumour system, IFN- $\alpha$ induced necrosis of vascular endothelial cells (35). This effect is similar to that of TNF- $\alpha$, known to elicit programmed cell death (apoptosis) of vascular endothelial cells (23).

IFN- $\alpha$ and $\beta$ downregulate the expression of mitochondrial genes for cytochrome $\mathrm{b}$ and $\mathrm{c}$ oxidase and $\mathrm{a}$ dehydrogenase (subunit 5 but not subunit 6) system. Cycloheximide inhibited this effect, thus implying the activation of an IFN-responsive gene(s) that encodes the synthesis of products with the capability to suppress genes or mRNA for the mitochondrial enzyme systems listed above (36). It is not yet understood how these novel effects of IFNs may affect tumour growth or angiogenesis.

\section{INHIBITORS OF ANGIOGENESIS OTHER THAN INTERFERONS}

In addition to the classical combination of heparin and corticosteroids $(37,38)$, fumagillin antibiotics (fumagillol) exert strong inhibitory effect on neovascularization and thus suppress metastasis formation by murine tumours (39). Krestin, the mycelial polysaccharide of Coriolus versicolor, is a strong inhibitor of tumour-induced angiogenesis (40). Human recombinant platelet factor 4 and its analogues emerge as potent natural inhibitors of angiogenesis (41).

\section{SUMMARY}

Combinations of lymphokines, monokines, cytokines and growth factor inhibitors antagonistic to neovascularization have been identified and developed. Kaposi's sarcoma provides an excellent in vitro and in vivo model system for the study of angiogenesis inhibitors. Inhibitors of tumour-induced neovascularization thus identified may be of great clinical value in suppressing the growth and metastasis formation of highly malignant tumours.

\section{REFERENCES}

1. White CW, Sondheimer HM, Crouch EC, Wilson H, Fan LL. Treatment of pulmonary hemangiomatosis with recombinant interferon alpha-2a. N Engl J Med 1989;320: 1197-200.

2. Folkman J. Successful treatment of an angiogenic disease. N Engl J Med 1989;320:1211-2.

3. Sidky YA, Borden EC. Inhibition of angiogenesis by interferons: Effect on tumor- and lymphocyte-induced vascular responses. Cancer Res 1987;47:5155-61.

4. Sinkovics JG, Szakacs JE. Kaposi's sarcoma. In: Lapis K. Eckhardt S, eds. Lectures and Symposia, 14th International Cancer Congress. Basel: Karger, 1986:223-44.

5. Lane HC, Kovacs JA, Feinberg J, et al. Anti-retroviral effects of interferon-a in AIDS-associated Kaposi's sarcoma. Lancet 1988;ii:1218-22.

6. Wit RD, Schattenkerk JKME, Boucher CAB, Bakker PJM,
Veenhof KHN, Danner SA. Clinical and virological effects of high dose recombinant interferon- $\alpha$ in disseminated AIDS-related Kaposi's sarcoma. Lancet 1988;ii:1214-7.

7. Evans LM, Itri LM, Campion M, et al. Interferon- $\alpha 2 a$ in the treatment of acquired immunodeficiency syndrome-related Kaposi's sarcoma. J Immunother 1991;10:39-50.

8. Gelmann EP, Preble OT, Steis R, et al. Human lymphoblastoid interferon treatment of Kaposi's sarcoma in the acquired immune deficiency syndrome. Am J Med 1985;78:737-41.

9. Sinkovics JG. Oncogenes and growth factors. CRC Crit Rev Immunol 1988;8:217-98.

10. Krigel RL, Padavic-Shaller KA, Rudolph AR, Poiesz BJ, Comis RL. Exacerbation of epidemic Kaposi's sarcoma with a combination of interleukin-2 and $\beta$-interferon: results of a phase 2 study. J Biol Resp Modif 1989;8:359-65.

11. Friesel R, Komoriya A, Maciag T. Inhibition of endothelial cell proliferation by gamma interferon. J Cell Biol 1987; 104:689-96.

12. Sinkovics JG, Campos LT, Gyorkey F, Gyorkey P, Melnick JL. Kaposi sarcoma. International Congress for Infectious Diseases, Cairo, 1985:133. (Abst)

13. Salahuddin SZ, Nakamura S, Biberfield P, et al. Angiogenic properties of Kaposi's sarcoma-derived cells after long-term culture in vitro. Science 1988;242:430-3.

14. Nakamura S, Salahuddin SZ, Biberfield P, et al. Kaposi's sarcoma cells: Long-term culture with growth factor from retrovirus-infected $\mathrm{CD} 4^{+} \mathrm{T}$ cells. Science 1988:242:426-30.

15. Ensoli B, Nakamura S, Salahuddin SZ, et al. AIDS-Kaposi's sarcoma-derived cells express cytokines with autocrine and paracrine growth effects. Science 1989;243:223-6.

16. Ensoli B, Barillari G, Salahuddin SZ, Gallo RC, Wong-Staal F. Tat protein of HIV-1 stimulates growth of cells derived from Kaposi's sarcoma lesions of AIDS patients. Nature 1990;245:84-6.

17. Gill PS, Naidu YM, Salahuddin SZ. Recent advances in AIDS-related Kaposi's sarcoma. Curr Opin Oncol 1990;2:1161-6.

18. deMel WCP, Hoffband AV, Giles FJ, Goldstone AH, Mehta $\mathrm{AB}$, Ganeshguru K. Alpha interferon therapy for haematological malignancies: Correlation between in vivo induction of the $2^{\prime}, 5^{\prime}$ oligoadenylate system and clinical response. Br J Haematol 1990;74:452-6.

19. Schroder HC, Ugarkovic D, Wenger R, Raeter P, Okamoto $\mathrm{T}$, Muller WEG. Binding of Tat protein to TAR region of human immunodeficiency virus type I blocks TAR-mediated activation of $\left(2^{\prime}, 5^{\prime}\right)$ oligoadenylate synthetase. AIDS Res Human Retrovir 1990;6:659-72.

20. Basilico C, Newman KM, Curatola AM, et al. Expression and activation of the K- $f g f$ oncogene. Ann NY Acad Sci 1989;567:95-103.

21. Xerri L, Hassoun J, Planche J, et al. Fibroblast growth factor gene expression in AIDS-Kaposi sarcoma detected by in situ hybridization. Am J Pathol 1991;138:9-15.

22. Ruta M, Burgess W, Griol D, et al. Receptor for acidic fibroblast growth factor is related to the tyrosine kinase encoded by the fms-like gene (FLG). Proc Natl Acad Sci USA 1989;86:8722-6.

23. Robaye B, Mosselmans R, Fiers W, Dumont JE, Galand P. Tumor necrosis factor induces apoptosis (programmed cell death) in normal endothelial cells in vivo. Am J Pathol 1991;138:447-53.

24. Miles SA, Rezai AR, Sabazar-Gonzalez JF, et al. AIDS Kaposi sarcoma-derived cells produce and respond to 
interleukin 6. Proc Natl Acad Sci USA 1990;87:4068-72.

25. Sinkovics JG. Kaposi's sarcoma: Its 'oncogenes' and growth factors. CRC Crit Rev Haematol Oncol 1991;11:87-107.

26. Adelaide J, Mattei M-G, Marics I, et al. Chromosomal localization of the hst oncogene and its co-amplification with the int-2 oncogene in a human melanoma. Oncogene 1988;2:413-6.

27. Halaban R, Kwon BS, Ghosh S, Bovi PD, Baird A. bFGF as an autocrine growth factor for human melanomas. Oncogene Res 1988;3:177-86.

28. Creagen ET, Ahmann DL, Frytak S, Long HJ, Chang MN, Itri LM. Three consecutive phase 2 studies of recombinant interferon alpha-2a in advanced malignant melanoma. Cancer 1987;59:638-46.

29. Weidner N, Semple JP, Welch WR, Folkman J. Tumor angiogenesis and metastasis: Correlation in invasive breast carcinoma. N Engl J Med 1991;324:1-8.

30. Grover B, Hynes NE. Mutations in human breast cancer cells: Dominantly acting oncogenes and tumor suppressor genes suggest strategies for targeted interference. Int J Cancer Suppl 1990;5:40-6.

31. Dickson C. Role of the int-genes in murine mammary tumor development and implication for human breast cancer. Int J Cancer Suppl 1990;5:51-4.

32. Came PE, Moore DH. Studies on interferon induction by the mouse mammary tumor virus. Proc Soc Exp Biol Med 1970;133:252-4.

33. Maxwell M, Naber SP, Wolfe HJ, et al. Expression of angiogenic growth factor genes in primary human astrocytomas may contribute to their growth and progression. Cancer Res 1991;51:1345-51.

34. Boetius J, Blomgren H, Collins VP, Greitz T, Strander H. The effect of systemic human interferon-alpha administration to patients with glioblastoma multiforme. Acta Neurochirurg 1983;68:239-51.
35. Dvorak HF, Gresser I. Microvascular injury in pathogenesis of interferon-induced necrosis of subcutaneous tumors in mice. J Natl Cancer Inst 1989;81:497-502.

36. Shan B, Vasquez E, Lewis JA. Interferon selectively inhibits the expression of mitochondrial genes: A novel pathway for interferon-mediated responses. EMBO J 1990;9:4307-14.

37. Folkman J, Langer R, Linhardt RJ, Haudenschild C, Taylor S. Angiogenesis inhibition and tumor regression caused by heparin or a heparin fragment in the presence of cortisone. Science 1983;221:719-25.

38. Kerbel RS. Inhibition of tumor angiogenesis as a strategy to circumvent acquired resistance to anti-cancer therapeutic agents. BioEssays 1991;13:31-6.

39. Anon. Exploiting angiogenesis. Lancet 1991;337:208-9. (Edit)

40. Kumar S. Control of tumor growth: Endothelial cells as an alternative target. Anticancer Res 1990;10:1443-4.

41. Maione TE, Gray GS, Petro J, et al. Inhibition of angiogenesis by a recombinant human platelet factor 4 and related peptides. Science 1990;247:77-9.

42. Turner M, Chantry D, Katsikis P, et al. Induction of the interleukin 1 receptor antagonist protein by transforming growth factor- $\beta$. Europ J Immunol 1991;21:1635-9.

43. Wakabayashi G, Gelfand JA, Burke JF, Thompson RC, Dinarello CA. A specific receptor antagonist for interleukin 1 prevents Escherichia coli-induced shock in rabbits. FASEB 1991;5:338-43.

44. Dubois CM, Ruscetti FW, Palaszynski EW, et al. Transforming growth factor $\beta$ is a potent inhibitor of interleukin 1 (IL-1) receptor expression: Proposed mechanism of inhibition of IL-1 action. J Exp Med 1990; 172:737-44.

45. Cozzolino F, Torcia M, Aldinucci D, et al. Interleukin-1 is an autocrine regulator of human endothelial cell growth. Proc Natl Acad Sci USA 1990;87:6487-91. 


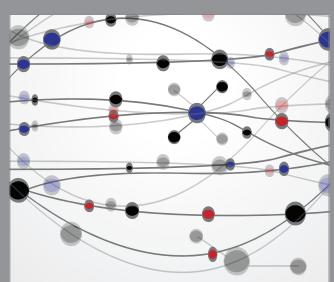

The Scientific World Journal
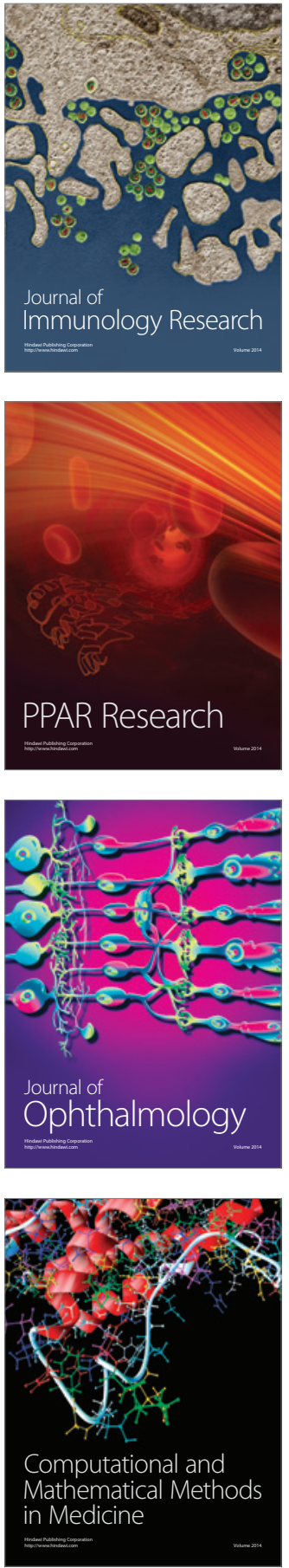

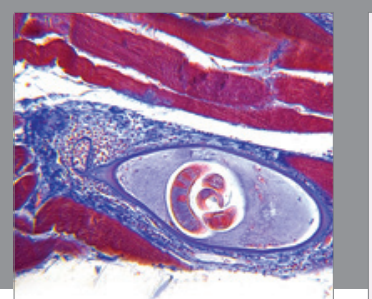

Gastroenterology Research and Practice

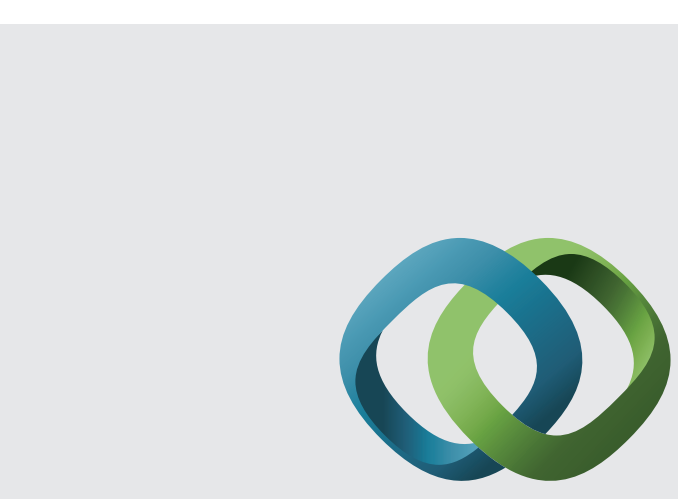

\section{Hindawi}

Submit your manuscripts at

http://www.hindawi.com
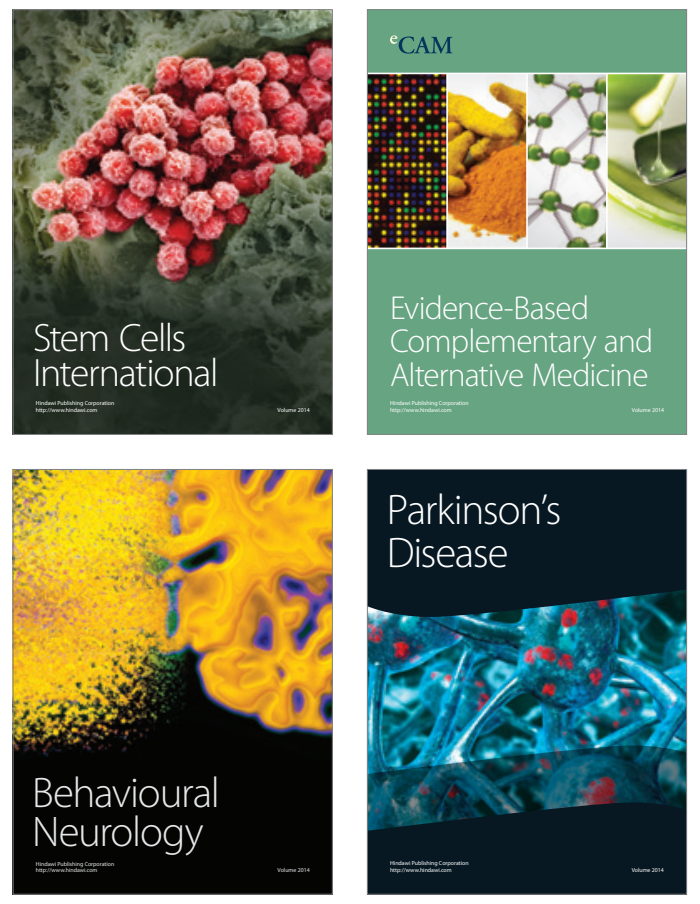
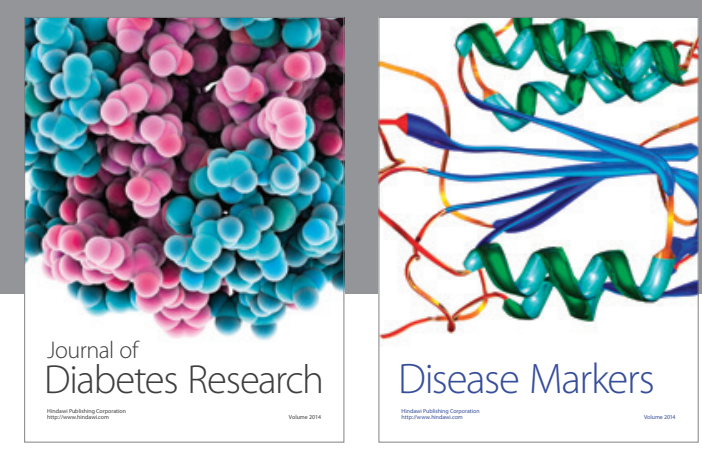

Disease Markers
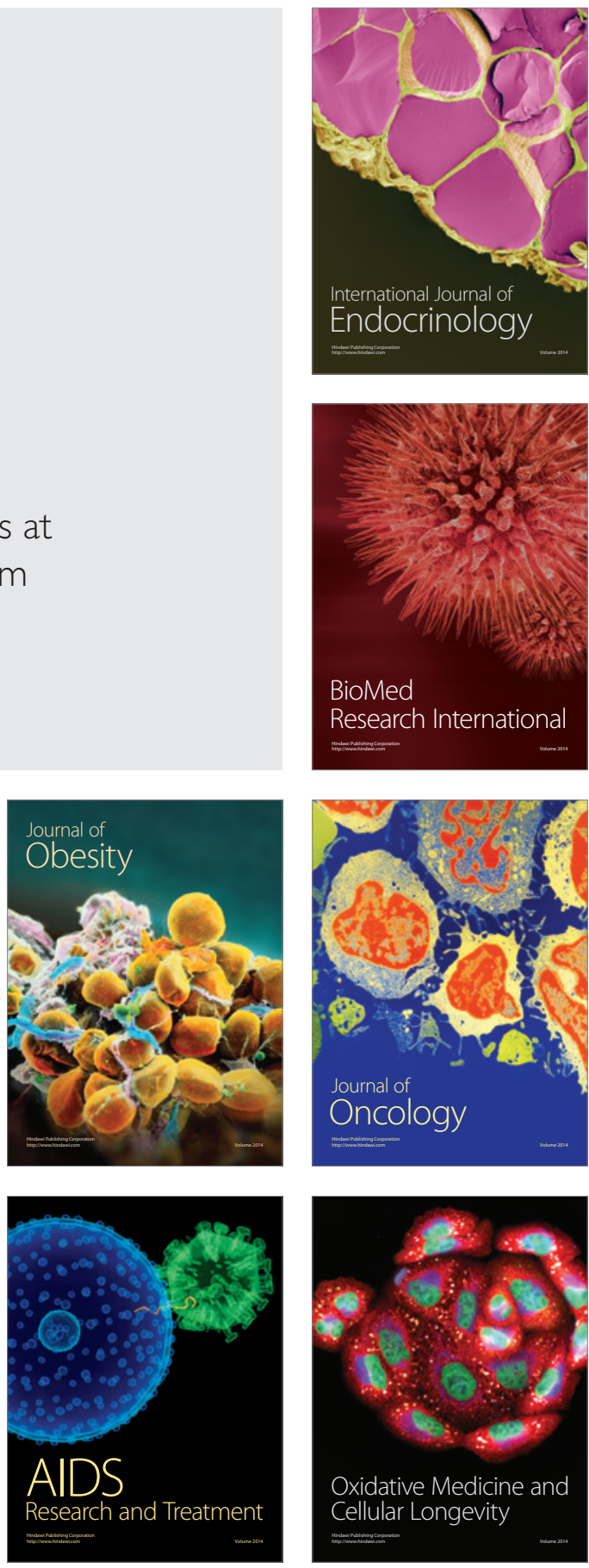